\title{
PHARMACOGNOSTIC STUDIES ON MILLINGTONIA HORTENSIS L.
}

\author{
Kavitha, A. and V. Mary Kensa* \\ Department of Botany and Research Centre, S.T. Hindu College, Nagercoil - 629002, Kanyakumari Dt. \\ *Email: surejkensa@gmail.com
}

\begin{abstract}
The earth is home to a rich and diversity assemblage of living organisms. Natural plant products play a dominant role in the development of novel drug leads for the treatment and prevention of diseases. The phytochemical screening and qualitative estimation of Millingtonia hortensis showed that the leaves were rich in steroids, terpenoids, fatty acids, tannins, saponins, anthocyanins, coumarins and emodins. Sulphated ash was higher than the total ash, acid insoluble ash and water soluble ash. The information obtained from the present study is useful during the time of collection and also during extraction process. Using these standards, the plant can be differentiated from other related species. This study will contribute to the existing knowledge over the standardization aspects of the raw drug M. hortensis.
\end{abstract}

\section{Keywords: Adulteration, Millingtonia hortensis, sulphated ash and parameters.}

\section{INTRODUCTION}

Nature has provided a complete store house of remedies to cure all ailments of mankind. Plants are a reliable source of potentially important bioactive natural products (Kavitha et al., 2004) and are used as traditional medicines and pharmacopoeial drugs. The majority of plants used in the Indian traditional system of medicine have not yet been screened for their pharmacological activities related to their growth condition. Plants may serve as the base for the development of a medicine, natural blue print for the development of new drugs or a phytomedicine. The current estimation of the number of flowering plants ranges between 2, 00,000 and 2, 50,000 species in 300 families and 10,500 genera (Iwu, 1993; Marimuthu et al., 2008). Methanolic extracts of Cassia alata root showed anthraquinones (Jain et al., 2010); methanol extract of rhizome of Cyperus tagetum showed the presence of alkaloids, glycosides, proteins, amino acids, phenols, flavonoids, tannins and saponins (Nitai et al., 2010). The pharmacognostic studies on leaf of Merugnkilanzhu showed the presence of cyclocytic stomata, unicellular trichome and conjoint, collateral vascular bundle (Brinda et al., 1981); in Holoptea integrifolia leaf, the vessels are present in broken and curved form (Benjamin and Patrick, 2002); numerous calcium oxalate crystals, numerous trichomes on both surfaces, chemo microscopic characters include lignin, starch, cellulose and mucilage were noted in Mitracarpusscaberleaf (Abere et al., 2007); Presence of pitted xylem vessels and cluster type of oxalate crystals were noted in the leaf of Amaranthus spinosus (Chumbhale et al., 2009). Rananculaceous type of stomata, cortex are impregnated by schizogenous and laticiferous ducts, vein islets and veinlet termination are characteristics in leaf architecture and uniseriatebicellular, uniseriate multicellular trichomes in the Gymnema sylvestre leaf (Deokule and Pokharkar, 2010); glandular trichomes, arch shaped vascular bundle (mid rib), anisocytic type of stomata with three subsidiary cells, large number of fibers, prism type oxalate crystals and lignifiedxylem vessels with bordered pits in the leaf of Physalis angulate (Santhya et al., 2010). The literature survey shows scanty information available on the pharmacognostic and phytochemical properties of Millingtonia hortensisgrow in study area. This promoted the present investigation to study the pharmacognostic, phytochemical properties of the above mentioned plant.

\section{MATERIALS AND METHODS}

\subsection{Plant material}

Fresh leaves of Millingtonia hortensis free from diseases were collected during the month of July 2015 from S.T. Hindu college campus, Kanyakumari District,Tamil Nadu, India (Elevation about 420 meters (Mean Sea Level). Millingtonia hortensisis used to carry out the pharmacognostic and phytochemical properties. Taxonomic identification of the plants was carried out with the help of Gamble (1957) and also compared with the herbarium present in Department of Botany, S.T. Hindu College, Nagercoil. 


\subsection{Extraction}

The leaves were washed thoroughly 2-3 times with running tap water, leaf material was then air dried under shade after complete shade drying the plant material was grinded in mixer, the powder was kept in small plastic bags with paper labeling. The grinded leaves material of $5 \mathrm{gm}$ weighed using an electronic balance and was crushed in $25 \mathrm{ml}$ of sterile water, boiled at $50-60^{\circ} \mathrm{C}$ for 30 minutes on water bath and it was filtered through Whatman No.1 filter paper. Then filtrate was centrifuged at $2500 \mathrm{rpm}$ for 15 minutes and filtrate was stored in sterile bottles at $5^{\circ} \mathrm{C}$ for further use (Harbone,1973)

2.3. Preparation of whole plant dry powder of selected species

The selected species were collected and dried separately at room temperature $\left(30 \pm 2^{\circ} \mathrm{C}\right)$ for about two weeks to get a constant weight. The dried leaf were ground to powder by mechanical device and stored for further biochemical analysis.

\subsection{Preparation of plant extracts for preliminary phytochemical screening}

The leafdrypowder samples were extracted with different solvents such as water, methanol, and chloroform at $20 \%(\mathrm{w} / \mathrm{v})$ level in a soxhlet apparatus. The extracts were concentrated and used for qualitative phytochemical analysis.

\subsection{Phytochemical Screening}

Preliminary qualitative phytochemical screening was carried out with the following methods.

\subsubsection{Steriods}

$1 \mathrm{ml}$ of the extract was dissolved in $10 \mathrm{ml}$ of chloroform and equal volume of concentrated sulphuric acid was added by sides of the test tube. The upper layer turns red and sulphuric acid layer showed yellow with green fluorescence. This indicated the presence of steroids (Gibbes, 1974).

\subsubsection{Terpenoids}

$2 \mathrm{ml}$ of extract was added to $2 \mathrm{ml}$ of acetic anhydride and concentration of $\mathrm{H}_{2} \mathrm{SO}_{4}$. Formation of blue, green rings indicates the presence of terpenoids (Ayoola, 2008).

\subsubsection{Fatty Acids}

$0.5 \mathrm{ml}$ of extract was mixed with $5 \mathrm{ml}$ of ether. These extract was allow it for evaporation on filter paper and dried the filter paper. The appearance of transparence on filter paper indicates the presence of fatty acids (Ayoola, 2008).

\subsubsection{Tannins}

$2 \mathrm{ml}$ of extract was added to few drops of $1 \%$ lead acetate. A yellowish precipitate indicated the presence of tannins (Paris, 1969).

\subsubsection{Saponins}

$5 \mathrm{ml}$ of extract was mixed with $20 \mathrm{ml}$ of distilled water and then agitated in a graduated cylinder for 15 minutes. Formation of foam indicates the presence of saponins (Gibbes,1974).

\subsubsection{Anthocyanins}

$2 \mathrm{ml}$ of aqueous extract is added to $2 \mathrm{ml}$ of $2 \mathrm{~N} \mathrm{Hcl}$ and ammonia. The appearance of pink-red turn's blue-violet indicates the presence of anthocyanins (Paris, 1969).

\subsubsection{Leucoanthocyanins}

$5 \mathrm{ml}$ of aqueous extract added to $5 \mathrm{ml}$ of isoamyl alcohol. Upper layer appears red in colour indicates for presence of leucoanthocyanins (Gibbes,1974)

\subsubsection{Coumarins}

$3 \mathrm{ml}$ of $10 \% \mathrm{NaOH}$ was added to $2 \mathrm{ml}$ of aqueous extract formation of yellow colour indicates the presence of coumarins (Rizk, 1982).

\subsubsection{Emodins}

$2 \mathrm{ml}$ of $\mathrm{NH}_{4} \mathrm{OH}$ and $3 \mathrm{ml}$ of Benzene was added to the extract. Appearance of red colour indicates the presence of emodins. (Rizk, 1982).

\subsubsection{Ash values}

Ash values such as total ash, acid insoluble ash, water-soluble ash, and sulfated ash were determined according to Indian pharmacopoeia.

\subsection{Pharmacognostic Studies}

\subsubsection{Macroscopic Studies}

Mature and healthy plants of Millingtonia hortensiswere collected to study the morphological characters. By using hand lens in the field and dissection microscope in the laboratory, micro and macroscopic characters of the plantare recorded.

\subsubsection{Microscopic (Anatomy) Studies}

\subsubsection{Collection and Preparation of Specimens}

Care was taken to select healthy plants of normal growth. The required samples of different plant parts were cut and fixed in a mixture of FAEA 
( $5 \mathrm{ml}$ Formalin $+5 \mathrm{ml}$ Acetic acid $+90 \mathrm{ml}$ of $70 \%$ Ethyl Alcohol). After $24 \mathrm{hrs}$ of fixing, the specimens were dehydrated with graded series of tertiary-butyl alcohol as per the method given by Sass (1940). Infiltration of the specimens was carried out by gradual addition of paraffin wax (melting point 58$60^{\circ} \mathrm{C}$ ) until TBA solution attained super saturation. The specimens were cast into paraffin blocks.

\subsubsection{Sectioning}

The paraffin embedded specimens were sectioned with the help of Rotary Microtomes. The thickness of the sections was 10-12 mm. De-waxing of the sections was done by customary procedure (Johansen, 1940). The sections were stained with Toluidine Blue as per the method of O'Brien et al. (1964). Since toluidine blue is a polychromatic stain, the staining results were remarkably good and some cytochemical reactions were also obtained. The dye rendered pink colour to the cellulose walls, blue to the lignified cells, dark green to suberin, violet to the mucilage, blue to the protein bodies, etc. Wherever necessary, sections were also stained with safranin and Fast-green and IKI (Iodine Potassium Iodide) for starch.

\subsubsection{Photomicrographs}

Microscopic descriptions of tissues are supplemented with micrographs wherever necessary. Photographs of different magnifications were taken with Nikon Labphoto-2 microscopic unit. For normal observations, bright field microscope was used. For the study of crystals, starch grains and lignified cells, polarized light microscope was employed. Since these structures have birefringent property, under polarized light microscope they appear bright against dark background. Magnifications of the figures are indicated by the scale -bars. Descriptive terms of the anatomical features are as given in the standard anatomy books (Esaa, 1964).

\section{RESULTS AND DISCUSSION}

\subsection{Description}

Millingtonia hortensis L. (Family : Bignoniaceae) is a tall deciduous tree grows to a height of about 18 to $25 \mathrm{~m}$ and can reach a maximum of about $80 \mathrm{~m}$, spread to an area of 7 to $11 \mathrm{~m}$. The tree bears a straight trunk with corky bark and lesser branches. It flowers at the night and shed flowers early in the morning.

\subsection{Leaves}

The leaves are large, ornamental,

imparipinnate, opposite, tripinnately compound, exstipulate, petiolated. The upper tertiary leaflets are sessile, exstipullate and are ovate-lanceolate with a rounded or cuneate base, serrate margins with acuminate tips and 1-3 inches long.

\subsection{Inflorescence}

Paniculate cymes (terminal or axillary).

\subsection{Flowers}

Flowers are white, waxy, trumpet shaped and somewhat 2 lipped with 5 sub equal lobes. The tree flowers twice a year and the white flowers come as large panicles which emit a pleasant fragrance. They are bisexual, zygomorphic. The bell-shaped sepals of the flower have five small lobes with four stamens and paralleled anthers. The corolla is a long tube with 5 lobes.The lobes are valvate, ovate-lanceolate, densely pubescent adaxially margin. Ovary sessile, ovoid. Style long; stigma ligulate, compressed, 2lobed, slightly exerted from corolla tube. Flowering usually takes place from April until the rains and again in October to December.

\subsection{Fruits and Seeds}

Fruits are smooth, flat, 2 valved, septicidal capsule, oblong, acute at both ends, woody. The seeds are discoid, compressed, winged, except the base; the wing is narrow at the apex and nonendospermic. The fruiting period is NovemberFebruary.

\subsection{Microscopic (anatomical) studies}

\subsubsection{Microscopic characteristics of Millingtonia} hortensis

\subsubsection{Root}

The transverse section of Millingtonia hortensis root showed the presence of epiblema with single layer of cuticle. Unicellular root hairs are reported on the epiblema. Next to epiblema, 9-12 layer of parenchymatous cortex are present (homogenous) with intercellular spaces. Next to cortex, single layer of endodermis and pericycle. Then vascular bundles are present. Xylem is star shaped and thick. Phloem is present in the form of patches.

\subsubsection{Stem}

The transversesection of $M$. hortensisstem showed the presence of single layer of epidermis. Epidermis is covered by single layer of cuticle with epidermal hairs. Next to epidermis, heterogenouscortex is present. i.e, outer 
parenchymatous, middle chlorenchymatous and inner sclerenchymatous. Medullary rays are traverse in between the xylem. Pith is parenchymatous. Phloem tissues are massive in nature.

\subsubsection{Leaf}

Transverse section of leaf shows a typical dorsoventrally structure. The epidermis of both the structure is single layered. Epidermal cells are rectangular and covered externally with cuticle. The upper epidermal cells are slightly bigger. A number of cells of upper as well as lower epidermis are elongated and are covered by multicellular hairs. Stomata are rananculaceous type and are mostly confined on the lower epidermis.

Mesophyll is differentiated in to two layers, viz. palisade tissue and spongy tissue. Palisade tissue is two rows of elongated chloroplast. Spongy parenchyma cells are loosely arranged with intercellular spaces on the lower side. Mid rib portion is bulged towards adaxial side of the leaf. The vascular bundles are surrounded by the parenchymatous bundle sheath. The xylem is characterized by the presence of small vessels, tracheids and fibers. The xylem lies towards upper epidermis and phloem lies below the xylem i.e. towards lower epidermis.

The phytochemical screening and qualitative estimation of Millingtonia hortensis studied showed that the leaves were rich in steroids, terpenoids, fatty acids, tannins, saponins, anthocyanins, coumarins and emodins (Table 1). Preliminary qualitative studies according to Mallikh et al., 2007 is useful in the detection of bioactive principles and subsequently may lead to drug discovery and development. Vaghasiya et al., 2011 analyzed fifty three medicinal plants for phytochemical characterization.

Table 1. Preliminary phytochemical analysis of leaf in water, chloroform and methanol extract on $M$. hortensis $\mathrm{L}$.

\begin{tabular}{|c|c|c|c|}
\hline \multirow{2}{*}{$\begin{array}{c}\text { Phytochemical } \\
\text { group }\end{array}$} & \multicolumn{3}{|c|}{ Leaf } \\
\hline & Water & Chloroform & Methanol \\
\hline Alkaloids & - & - & - \\
\hline Steroids & - & + & + \\
\hline Terpenoids & + & + & + \\
\hline Fatty acids & - & + & + \\
\hline Tannins & + & + & + \\
\hline Saponins & + & + & + \\
\hline Anthocyanins & - & - & + \\
\hline Coumarins & + & - & + \\
\hline Emodins & - & - & + \\
\hline
\end{tabular}

Table 2. Ash analysisof leaf of $M$. hortensis.

\begin{tabular}{ccccc}
\hline $\begin{array}{c}\text { Plant } \\
\text { part }\end{array}$ & $\begin{array}{c}\text { Total } \\
\text { ash } \\
(\%)\end{array}$ & $\begin{array}{c}\text { Acid } \\
\text { insoluble } \\
\text { ash (\%) }\end{array}$ & $\begin{array}{c}\text { Water } \\
\text { soluble } \\
(\%)\end{array}$ & $\begin{array}{c}\text { Sulphated } \\
\text { ash (\%) }\end{array}$ \\
\hline Leaf & 10.5 & 6.0 & 2.0 & 15.0 \\
\hline
\end{tabular}

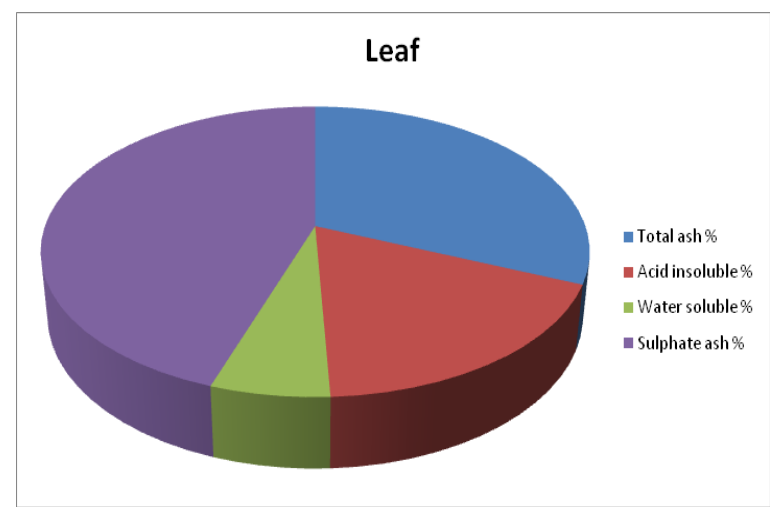

Fig. 1. Ash analysis of leaf of M.hortensis

Table 3. Colour analysis of leaf of $M$. hortensisafter treated with different chemicals.

\begin{tabular}{cc}
\hline Treatment & Leaf \\
\hline $\mathrm{HCL}$ & Brown \\
$\mathrm{H}_{2} \mathrm{SO}_{4}$ & Brown \\
$\mathrm{HNO}_{3}$ & Yellow \\
Acetic acid & Red \\
Iodine solution & Orange red \\
\hline
\end{tabular}

Four types of ash were determined of the leaf of $M$. hortensis and their percentage values were recorded in Table 2 and Fig. 1). Sulphated ash was higher than the total ash, acid insoluble ash and water soluble ash. Powders of leaf were treated with concentrated acids, Iodine solution and colour changes in the powder were recorded in Table 3

Ash values, colour under various acids and the qualitative evaluation of extract for the phytochemical groups were parameters used for the characterization of botanical drug, and these are the preliminary steps of the quality control for herbal drugs. Biological activity of crude drug is mainly due to the active chemical constituents, and the constituents may be soluble in different polar, semi polar andnon-polar solvents (Kokate et al., 2005).

Ash value of medicinal plants reflects the carbonate, phosphate, oxides, silicate and silica. Moreover the total ash of a crude drug also reflects the care taken in drug preservation, and the purity of crude and the prepared drug. Acid soluble ash reflects the calcium oxalate content of the drug. In the present investigation considerable amount of 
total ash was noticed in leaf, findings can be employed as quality parameter to evaluate $M$. hortensis biomass for any adulteration.

Phytochemical profiling of aqueous, chloroform and methanol extracts of leaf for steroids, terpenoids, fatty acids, tannins, saponins, anthocyanins, coumarins and emodins emerged with noticeable results. Like alkaloids were absent in leaf, same results were reported by Misra, 1909. Such outstanding phytochemical screening results can be good tool for identification of $M$. hortensis biomass particularly when grinded to fine powder.

Various studies have been demonstrated that coumarins are a potential antioxidant and its antioxidant activity is due to its ability to scavenge free radicals and to chelate metal ions (Tseng, 1991). Emodins isolated from a great deal of herbs are an effective constituent with many effects. Lots of pharmaceutical studies have demonstrated that emodin has many biological effects, such as anticancer, antimicrobial and anti-inflammatory effects (Wang et al., 2007). The growth of many fungi, yeasts, bacteria and viruses was inhibitedby tannins (Chung, 1998). Terpenoids and tannins are attributed for analgesic and anti-inflammatory activities. Apart from this, tannins contribute property of astringency (faster the healing of wounds and inflamed mucous membrane). Traditionally saponins have been extensively used as detergents, as pesticides and molluscicides is addition to their industrial applications as foaming and surface active agents and also have beneficial health effects (Shi et al., 2004).

$\begin{array}{rrrrr}\text { The } & \begin{array}{r}\text { following } \\ \text { supports }\end{array} \text { ourpresent } & \text { previous } & \text { studies } & \text { also } \\ \text { study, } & \text { roots } & \text { of }\end{array}$ Strychnonspotatorum (Mallikharjuna et al., 2007), leaves of Bauhinia racemose (Sharanabasappa et al., 2007), methanolic extract of roots and leaves of Hyptissuaveolens (Nwobu et al., 2010), ethanolic extracts of roots of Rumex vesicarius (Hari and Rama, 2011).

\subsection{Phytochemical studies}

Plants can manufacture many different types of secondary metabolites, which have been subsequently exploited by human beings for their beneficial role in a diverse array of applications.Often, plants secondary metabolites may be referred to as plant natural products, which have illicit effects on other organisms.

The results of present study showed that the plant parts of Millingtonia hortensis having rich primary and secondary metabolites such as alkaloids, tannins, phenols and starch can be used as industrial raw materials. Therefore, economic use depends partially on the quantitative and qualitative aspects of their organic reserves, specially carbohydrates, proteins, phenols and lipids. These metabolites are further used for biosynthesis of bioactive compounds.

Preliminary phytochemical screening of plants is very useful for the determination of the active constituents in different solvent extracts. Among the phytochemicals tested, terpenoids tannins andsaponins are reported in all the extracts of Millingtonia hortensis. Alkaloids are not reported.

However, there are variations in the presence and absence of phytochemical compounds in the various solvent extracts of the selected plant tested.Phytochemical and pharmacological studies of Bauhinia species have demonstrated the presence of flavonoids (Silva, 2002). Moreover some researchers reported that flavanones, flavones and flavones were the three types of flavonoids found in citrus fruits (Fernandez and Lopez, 2002; Calabro et al., 2004; Ebrahimzadeh et al., 2004; Jayaprakasha and Patil, 2007). Non- polar flavonoids have been isolated from bay leaves (Demo et al., 1998; Elmastas et al., 2004).

\section{CONCLUSION}

The pharmacognostic characters and phytochemical values reported in this plant could be used as the diagnostic tool for the standardization of this plant. Adulterants if any can be easily identified using these parameters. The microscopic features could help in laying down micro morphological standards as per WHO guidelines for authentication of the drug. Macroscopic as well as microscopic studies of any phytodrug are the primary steps to establish its botanical quality control before bring to other studies. As per WHO norms, botanical standards are to be proposed as a protocol for the diagnosis of the herbal drug. The above mentioned parameters are helpful for the future identification and authentication of the plant in the herbal industry and in factories. The ash values, colour under different chemicals will be useful to identify the authenticity of the drug even from the crushed or powdered plant materials. The information obtained from the present study is useful during the time of collection and also during extraction process. Using these standards, the plant can be differentiated from other related species. This study will contribute to the existing knowledge over the standardization 
aspects of the raw drug $M$. hortensis.

\section{REFERENCES}

Abere, S., R. Abdullah and I. Khali, (2007). Antimicrobial studies on Mitacarpus scaber. Ethnoleaflets 5:11-17.

Ayoola, G.A., H.A.B. Coker, A.A. Adesegun, K. Obaweya, E.C. Ezennia and T.O. Atangbayila, (2008). Phytochemical screening and antioxidant activities of some selected medicinal plants used for malaria therapy in South Western Nigeria. Trop. J. Pharm. Res. 7: 1019-1024.

Benjamin Jeya Kumar, P. and S. Christopher Patrick Kiladi, (2009). Preliminary phytochemical and pharmacognostic studies of Holoptea integrifolia. Ethnobotanical leaflets 13:1222-31.

Brinda, P., B. Sasikala and K.K. Purushothaman (1981). Pharmacognostic studies on Merugankilanzhu, BMEBR. 8:1-13.

Calabro, H.A., B.I. Abu Elreish and S.M. Yagi, (2004). Antaomical and phytochemical studies of the leaves and roots of Urginea grandiflora and Pancratium tortuosum. Ethnobotanical Leaflets 14:826-35.

Chumbhale Deshraj, S., D.N. Raut, M.V. Sabale, S.R. Chaudhari and C.D. Upasani, (2009). Pharmacognostic standardisation and physicchemical evaluations of Amaranthus spinosus. Int. Jr. Pharma Res. Develop. 4(2):1-3.

Chung, K.T., T.Y. Wong, C.L. Wei and Y.W. Huang, (1998).Tannins conservation. Edited by P.C. Trivedi. $2^{\text {nd }}$ revised edition: 95-103coumarins. Proc. Am. Assoc. Cancer.Res. 32: 2257.

Demo, B., B. Kamatchi Kala, V.R. Mohan and C. Kalidass, (1998). Pharmaco-chemical characterisation of Andrographis paniculata, Alpinia calcarata and Hiptage benghalensis. J. Econ. Taxon. Bot. 33(4): 940-946.

Deokule, S.S. and A.A. Pokharkar, (2010). Pharmacognostic study of leaf of Gymnema sylvestre. J. Econ. Taxon. Bot. 34(1):18-24.

Ebrahimzadeh, D., C.M. Karrunakaran, S. Selva Kumar and P.T. Palani Swamy, (2004). Identification of phytochemical constituents of Aegle marmelos responsible for antimicrobial activity against selected pathogenic organisms. Ethnobotanical leaflets 13:1362-1372.

Elmastas, G.V., A.K. Gupta and N. Tandon, (2004). Medicinal plants of India. Indian Council of
Medical Research, and New Delhi, India.

Elmastas, R., R. Kaur, and R. Arora, (2004). Studies on phytochemical constitutents of Costus mexicanus. Phytochemistry 37(4): 196-216.

Esaa, K. (1964). Anatomy of seed plants, $2^{\text {nd }}$ edition. Library of Congress. Cataloging in Publicaiton, 90-116.

Fernandez, S. and S. Opez, (2001). Antiparasitic properties of medicinal plants and other naturally occurring products. Adv. Parasitol. 50: 199-295.

Gamble, J.S. (1957). Flora of the presidency of Madras. Vol. 09, Calcutta: Botanical survey of India. 699.

Gibbes, R.D. (1974). Chemotaxonomy of Flowering Plants.Vol.1, McGill Queen's University, Press Montrealand London.

Harbone, J.B. (1973). Phytochemicals methods - A guide to modern techniques of plant analysis. Springer Netherlands.

Hari, M. and M. Rama, (2011). Millingtonia hortensis Linn - a review. Pharmacol. Online 2: 597-602.

Iwu, M. (1993). Handbook of African Medicinal Plants. CRC Press, Boca Raton, FL.

Jain, R., G. Chitale, P. Sharma and C. Jain, (2010). Phytochemical and antimicrobial investigations of Cassia alata roots. J. Med. Arom. Pl. Sci. 32:1315.

Jayaprakasha, K. and G. Patil, (2007). Pharmacognostical study of Hybanthu senneaspermus. Nat. Prod. Rad. 6(5):386-390.

Johansen, D.A. (1940). Plant Microtechnique. MC Graw Hill Book Co. Inc. New York and London., 523.

Kavitha, A., S. Chanda and I. Bosisio, (2004). Notes on ethnobotany of five districts of Garhwal Himalay, Uttarpradesh, India, Ethnobotany 5: 157-163.

Kokate, K.S., R. Hannah, S. Vasanthi and G.V. Rajamanickam, (2005). Ethnobotany, phytochemistry and pharmacology of Mussaenda pupescence (Rubiaceae). Ethnobotanical Leaflets 12:469-475.

Mallikharjuna, P.B., L.N. Rajanna, Y.N. Seetharam and Sharanabasappa, (2007). Antibacterial and antioxidant properties of the methanol extracts of the leaves and stems of Calpurnia aurea. BMC Comp. Alt. Med. 52:8-15.

Marimuthu, P., C.L. Wu, H.T. Chang and S.T. Chang, 
(2008). Antioxidant activity of the ethanolic extract from the bark of Chamaecyparis obtuse var. Formosana. J. Sci. Food Agric. 88:14001405.

Misra, R. (1909). Chemodiversity and the biological role of secondary metabolites, some thoughts for selecting plant material for drug development. Proc. Phytochem. Soc. Europe, Kluwer Publishers, 43:11-24.

Nitai Chand, C., H. PallabKanti and M. Arup, (2010). In vitro free radical oils from Biden spilosa Linn. Var. radiata. Food Control 19:346-352.

Nwobu, B., A.D.B. Vaidhya and M. Chorghade (2010). Ayurveda and Natural products drug discovery. Curr. Sci. 86:789-799.

O'Brien, T.P., N. Feder and M.E. Mc Cull, (1964). Polychromatic staining of plant cells walls by Toluidine blue. Protoplasma 59:364-373.

Paris, R. and H. Moyse, (1969). Phytochemical profile and Antibacterial activity of stem bark of Anogeissus latifolia. Pharmacog. J. 2(17):70-73.

Rizk, A.M., (1982). Phytochemicals methods. Fitoterapia 52:35-42.

Sandhya, B., S. Thomas, W. Isabel and R. Shenbagarathai, (2006).Complementary and alternative medicines 3: 101-114.
Sharanabasappa, D., G. Balaji, M. Geetha, P. Manivachakam, R. Sumathi and S. Murugesan, (2007). Phytochemical screening of Phyllanthus emblica in different agroclimatic zones of Tamil Nadu. Pestology 33(3):15-20.

Shi, J., K. Arunasalam, D. Yeung, Y. Kakuda and G. Mittal, (2004). Evaluation of the wound healing activity of ethanolic extract of Morinda citrifolia. E. Cam. 6(3):351-356.

Silva, R.K. (2002).Pharmacological activity of Elaeocarpuss phaericus. Phytother. Res. 14:3639.

Tseng, A., (1991). Phytoestrogen concentration determines effects on DNA synthesis in human breast cancer cells. Nutr. Cancer 28(3): 236247.

Vaghasiya, H., M. Rojer and M. Wink, (2011). Medicinally important secondary metabolites in recombinant microorganisms or plants: progress in alkaloid biosynthesis. Biotech. J. 4(12): 1684-1703.

Wang, C.H., B. Gao, J.T. Ye, C.G. Cai, K.D. Xie and Q. Du, (2007). Scavenging capacity of berry crops on superoxide radicals. Jr. Agri. Food Chem. 48: 5677-5684. 